\title{
Intentional introduction of Biscutella laevigata L. on the post-flotation lead-zinc ore spoil heap in Piekary Śląskie (Upper Silesia, Southern Poland)
}

\author{
Adam Rostański \\ Department of Botany and Nature Protection, Faculty of Biology and Environmental Protection, University of Silesia, \\ Jagiellońska Str. 28, 40-032 Katowice, Poland \\ E-mail address: adam.rostanski@us.edu.pl
}

\begin{abstract}
The paper presents an account of the successful intentional introduction of the mountain species Biscutella laevigata to a lowland locality, as a result of field experiment - biological management at the toxic "Dołki" washery spoil heap (Lead and Zinc Ore Main and Factory) ZGH "Orzeł Biały" (Upper Silesia - Southern Poland). The aim of the presented study was to test the effectiveness possibilities of using the blend of seeds including a metallophyte - Biscutella laevigata seeds. The introduction of Biscutella laevigata was a part of an experiment which began in 2009-2010 with plots on the "Dolki" washery spoil heap. The tested seeds of Biscutella laevigata were examined for germination, growth and development in sites highly polluted with heavy metals. Biscutella laevigata appeared on two experimental plots. After 4 years there were numerous individuals of Biscutella - dozens of plants in various stages of development and phenology. Development of a Biscutella population from year to year (2 plants in 2010 - 58 plants in 2014) is larger and tends to increase. Biscutella individuals are spreading outside the designated test plots. The obtained results indicate that on sites highly polluted with heavy metals it is possible to perform a successful introduction of Biscutella laevgata population (increase from 2 individuals in 2010 to 58 individuals in 2014) from seeds. These results are also promising in terms of application as a new reclamation method.
\end{abstract}

KEY WORDS: mountain plant species, seed germination, biological reclamation, washery wastes $\mathrm{Zn}-\mathrm{Pb}$, field experiment

\section{Introduction}

The search for new methods of revegetation of areas with a high content of heavy metals in the soil (washery, flotation wastes) should promote the use of specific plant species useful in removing toxic elements, to stabilize or reduce the risk of the spread of pollutants in the environment (SALT ET AL., 1995).

In 2009-2010 the experiments with plots on washery waste dump area ZGH "Orzeł Biały" "Dołki" in Piekary Śląskie - Brzeziny began (RosTAŃSKI ET AL., 2012). This experiment tested four methods of biological reclamation: 1) transplantation of turves, 2) spreading hay (mulching) taken from dry meadows and grasslands, 3) sowing seeds of grassland species, which include seeds of mountain plant Biscutella laevigata, originating from the vicinity of Bolesław (Małopolska Upland).
The last method appeared to be the most successful. For this reason research was conducted, focused on the development of the newly established Biscutella laevigata population. The aim of the presented study was to describe the selected characteristics of the successfully introduced population of metallophyte - Biscutella laevigata.

\section{Material and methods}

\subsection{Study object - Biscutella laevigata L. - description of the species}

Biscutella laevigata (Brassicaceae) is a perennial plant occurring mainly in the mountains of central and northern Europe and the northern part of the Mediterranean - from the Pyrenees to the Transylvanian Alps.

Plants form rosette leaves at the root branching generative shoots, reaching up to $40 \mathrm{~cm}$ in height. 
Rosette leaves are oval-lanceolate, pubescent, serrated on the edge (up to $10 \mathrm{~cm}$ in length.). Fewer and smaller stem leaves are similar in shape to the rosette leaves. Flowers are yellow, numerous, and after flowering produce a rounded form with winged, flat sided fruits (siliques) with two flattened seeds (PAWLUS, 1985) (Fig. 1).

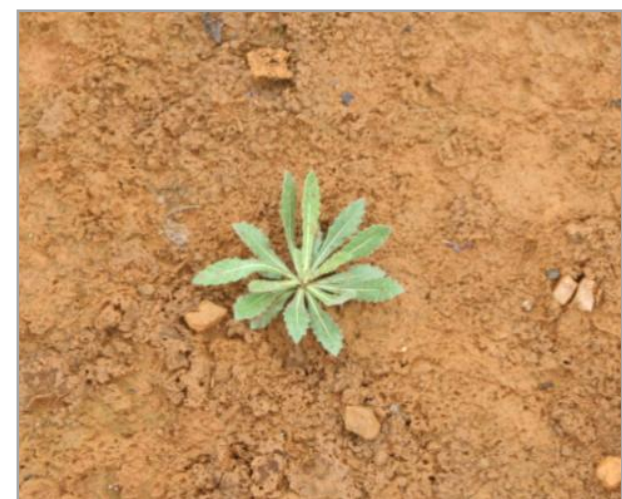

A

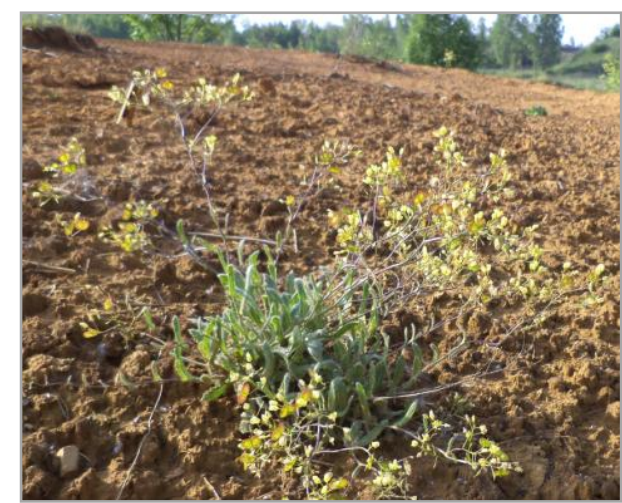

B

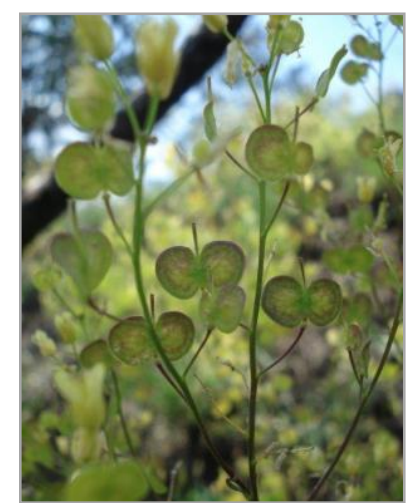

C

Fig. 1. The habit of plants of Biscutella laevigata: A) rosette leaves (A. Rostański), B) flowering plant (A. Rostański),

C) fruiting shoots (M. Jędrzejczyk-Korycińska)

Biscutella laevigata is a multi-zonal species of Alpine- and central European range-type. In Poland, this species is known from the Tatra Mountains (numerous localities) and in the uplands in the surroundings of Olkusz and Bolesław from calamine areas (ZAJĄC \& ZAJĄC, eds., 2001; NOWAK ET AL., 2011; BABST-KOSTECKA ET AL., 2014). An abundant locality of this species is also known from rocky grasslands in the surroundings of Kozubów in Nida Basin (PRZEMYSKI \& PIWOWARCZYK, 2012) (Fig. 2). Other localities in Poland are scarce and have an anthropogenic origin (ZAJĄC \& ZAJĄC, eds., 2001).
In natural mountain populations Biscutella laevigata is classified as a characteristic species of rocky grasslands in the order of plant communities Seslerietalia variae (PAWLUS, 1985). This plant is also classified as a metallophyte (DOBRZAŃSKA, 1955; WIERZBICKA \& ROSTAŃSKI, 2002; GRODZIŃSKA \& SZAREK-ŁUKASZEWSKA, 2009; KOWOLIK ET AL., 2010; SZAREK-ŁUKASZEWSKA, 2014). Its biological properties and tolerance to high concentrations of heavy metals in the soil indicates it as an important plant in the phytostabilization of calamine grasslands (WIERZBICKA \& ROSTAŃSKI, 2002).

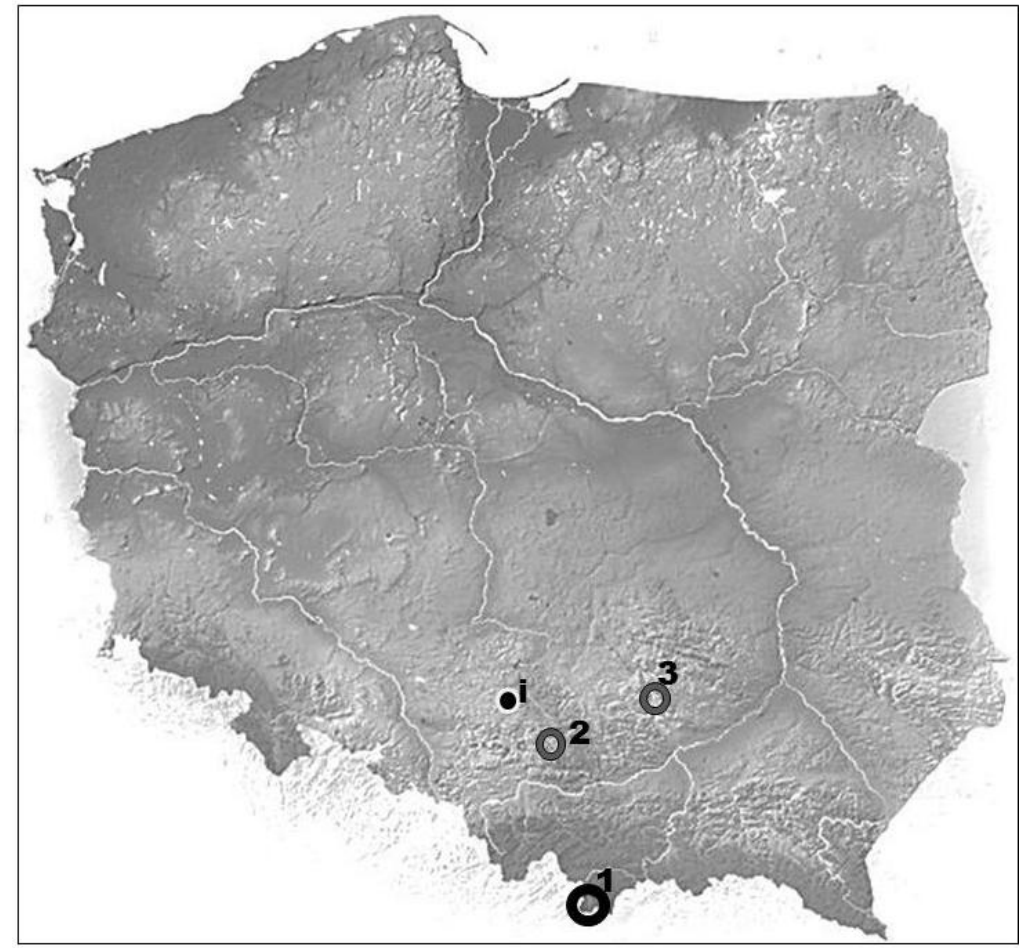

Fig. 2. The locations of the known Biscutella laevigata localities in Poland: 1 - Tatra Mts., 2 - Olkusz - Boleslaw Ore-bearing Region; 3 - Kozubów (Nida Basin), and i - the place of the introduction - Piekary Śląskie "Dołki" (Upper Silesia) 


\subsection{Site of introduction}

The site of the Biscutella laevigata seeds introduction (as a part of the reclamation project ROSTAŃSKI ET AL., 2012) was the washery waste heap from the processing of zinc and lead ores, located in the settlements "Dołki" at Światowida Str. in Piekary Śląskie - (Figs. 3, 4). The establishment of the waste heap dates back to 1915-1930 (KUCHARSKI ET AL., 2010). The area is clearly separated from the surrounding environment (elevation about $11 \mathrm{~m}$ ) and occupies ca. 1.2 ha. The wastes gathered here are highly toxic and include, among others, approx. $6 \%$ zinc, $1.5 \%$ lead and $0.1 \%$ of cadmium (KUCHARSKI ET AL., 2010). Due to its relatively significant age (approx. 90 years), the dumping ground has a fairly well developed vegetation, functioning as a phyto-stabilizer in relation to accumulated waste. The plant cover is not developed evenly on the whole surface of the heap. Especially the top part is not covered with spontaneous vegetation (Fig. 5).

Waste material deposited on a heap provides unfavorable conditions for plant growth due to the significant concentration of heavy metals and other physico-chemical parameters (Tab. 1,2).

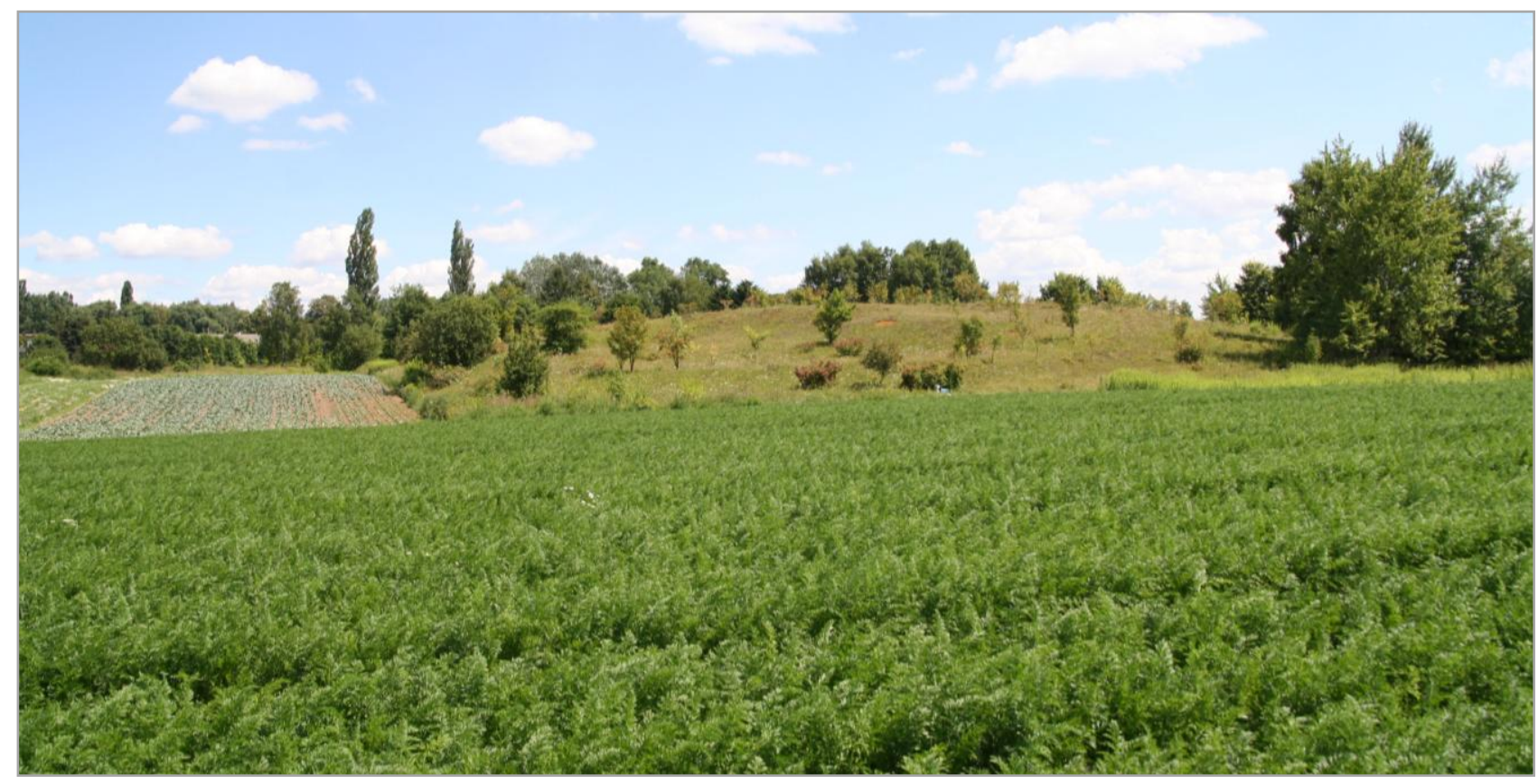

Fig. 3. The "Dołki" washery spoil heap in the Brzeziny Śląskie n. Piekary surrounded by its agricultural landscape (A. Rostański)

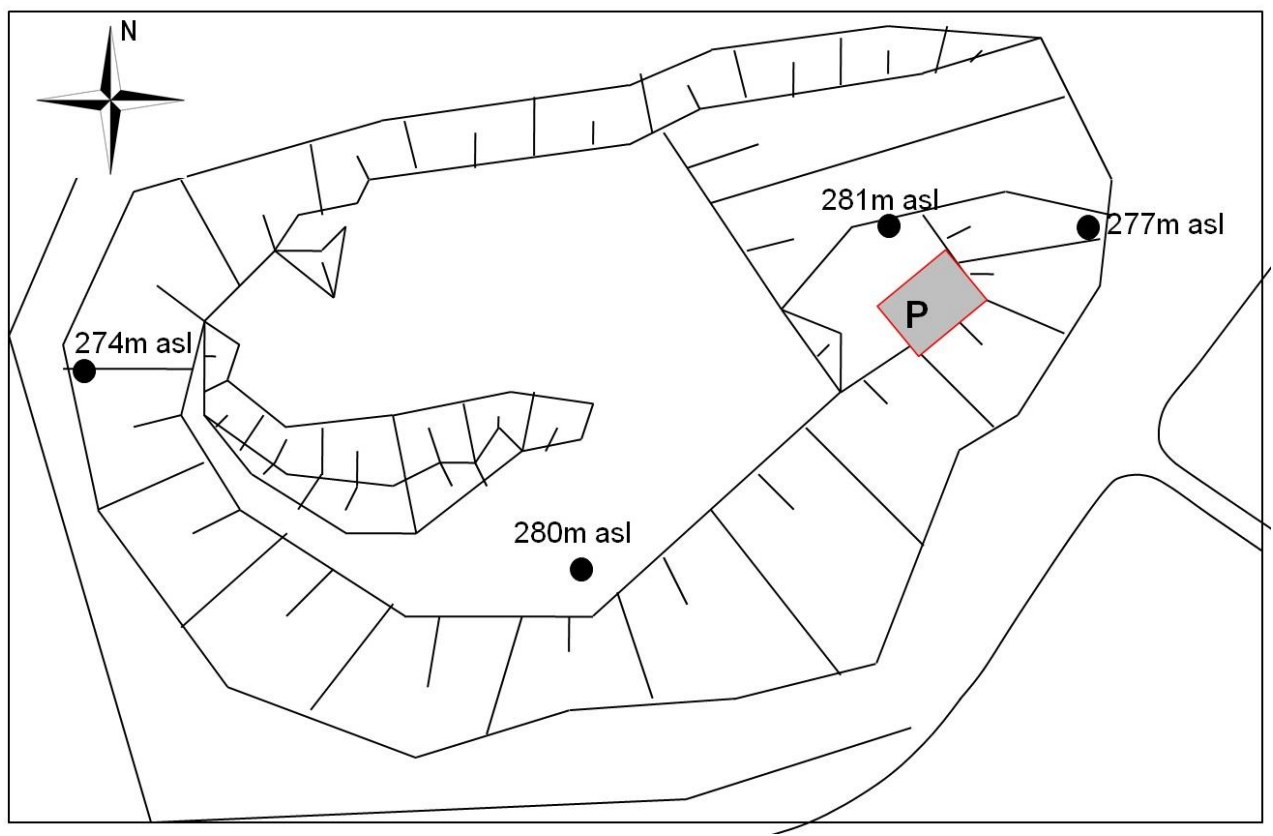

Fig. 4. Scheme of the research layout - "Dołki" washery spoil heap ZGH "Orzeł Biały" in Piekary Śląskie. The symbol P indicates the location of the experiment 
Table 1. Physico-chemical characteristic of ground (wastes) (after Kucharski et al., 2010, changed)

\begin{tabular}{|c|c|c|c|}
\hline \multicolumn{3}{|c|}{ Physico-chemical parameters } \\
\hline Parameter & $\mathrm{pH} \mathrm{H}_{2} \mathrm{O}$ & $\mathrm{pH} \mathrm{KCl}$ & Electrical conductivity EC [mS] \\
\hline value & $8.2-8.3$ & $7.9-8.0$ & $0.271-0.430$ \\
\hline
\end{tabular}

Table 2. Concentration of heavy metals of ground (wastes) (after Kucharski et al., 2010, changed)

\begin{tabular}{|c|c|c|c|c|c|}
\hline \multicolumn{2}{|c|}{ Metals } \\
\hline \multicolumn{2}{|c|}{ Zn } & \multicolumn{2}{c|}{$\mathrm{Cd}$} & \multicolumn{2}{c|}{$\mathrm{Pb}$} \\
\hline $\begin{array}{c}\text { total } \\
{[\mathrm{mg} / \mathrm{kg}]}\end{array}$ & $\begin{array}{c}\text { bioavailable } \\
{[\mathrm{mg} / \mathrm{kg}]}\end{array}$ & $\begin{array}{c}\text { total } \\
{[\mathrm{mg} / \mathrm{kg}]}\end{array}$ & $\begin{array}{c}\text { bioavailable } \\
{[\mathrm{mg} / \mathrm{kg}]}\end{array}$ & $\begin{array}{c}\text { total } \\
{[\mathrm{mg} / \mathrm{kg}]}\end{array}$ & $\begin{array}{c}\text { bioavailable } \\
{[\mathrm{mg} / \mathrm{kg}]}\end{array}$ \\
\hline $73000-89900$ & $72.6-88.9$ & $388.0-447.0$ & $1.60-3.50$ & $17700-18300$ & $1.50-2.97$ \\
\hline
\end{tabular}

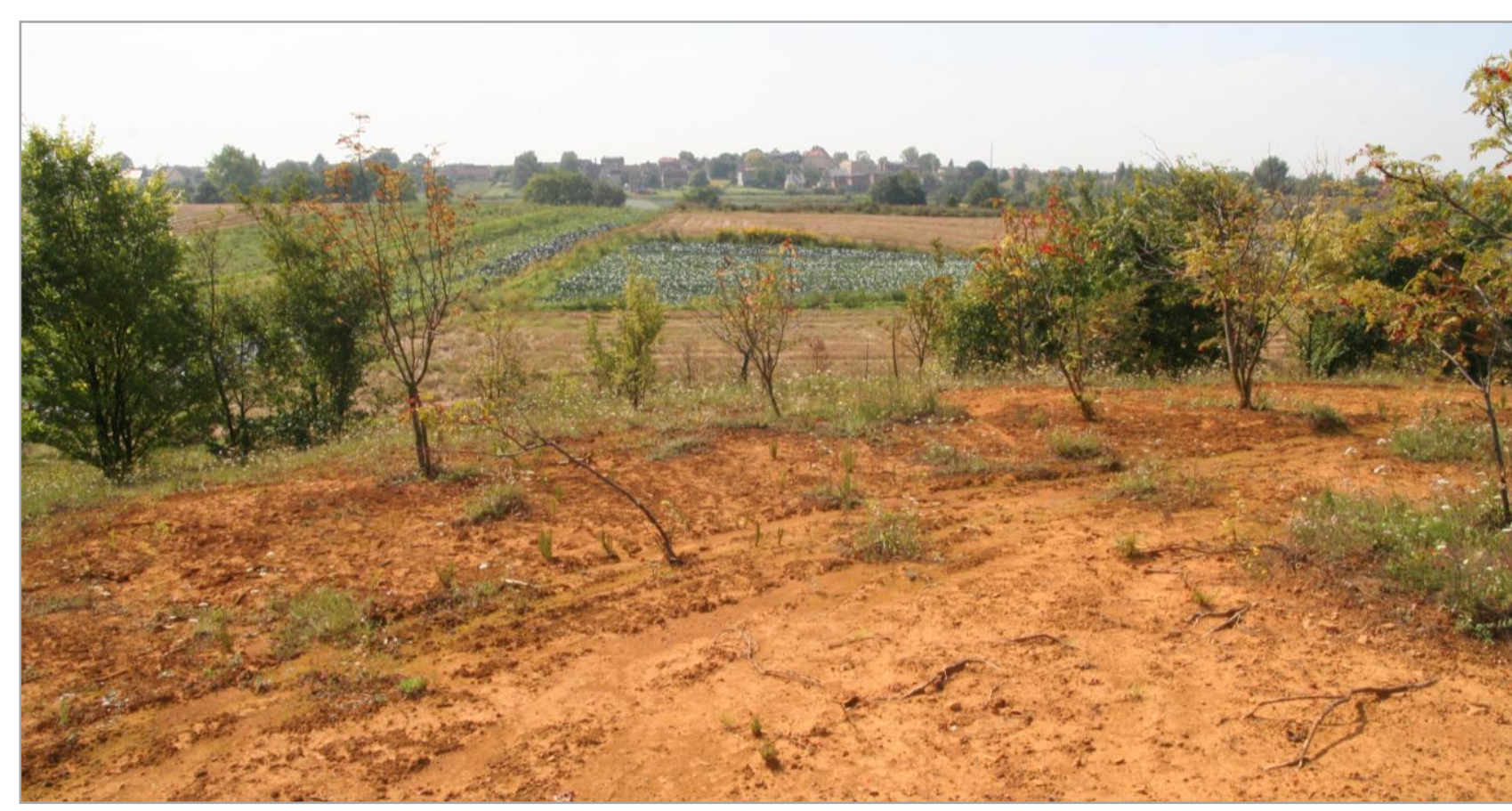

Fig. 5. The top of the "Dołki" spoil heap without vegetation cover (A. Rostański)

\subsection{Experimental plots}

In September 2009, at the "Dołki" spoil heap, in a place devoid of vegetation cover a plot-experiment was established (Figs. 5, 6). The research was designated on an area of $9 \times 4 \mathrm{~m}\left(36 \mathrm{~m}^{2}\right)$, where 36 plots were located $\left(1 \mathrm{~m}^{2}\right.$ each). The design of the field experiment is shown in Figure 7. Within the individual plots various experimental treatments were applied (RoSTAŃSKI ET AL., 2012):

(M) transplantation fragments of turf - 6 plots (turves were taken from the similar heaps in Tarnowskie Góry and implemented in the "Dołki" study area;

$(\mathrm{H})$ spreading hay (mulching) taken from grasslands and dry meadows was applied to 15 experimental plots (hay was collected from: - the
Kraków-Częstochowa Upland - near Smoleń village; - a washery waste heap in Tarnowskie Góry, - a washery heap "Dołki" in the Brzeziny Śląskie, - a xerothermic grassland in Strzyżowice, in the Tarnogórskie Hills area):

(S) sowing seeds - 9 plots (grassland plant seeds were collected directly in the field in 2009 from plants growing in Nakło Śląskie, in Bolesław; in the vicinity of Strzyżowice on Hump Tarnogórskie Hills, near Pińczów - Kielce District, and on the "Dołki" washery spoil heap (the main aim of the presented study);

(C) control plots (not treated) - 6 plots designated as controls.

Plots were placed in a random arrangement (Figs. $6,7)$. 


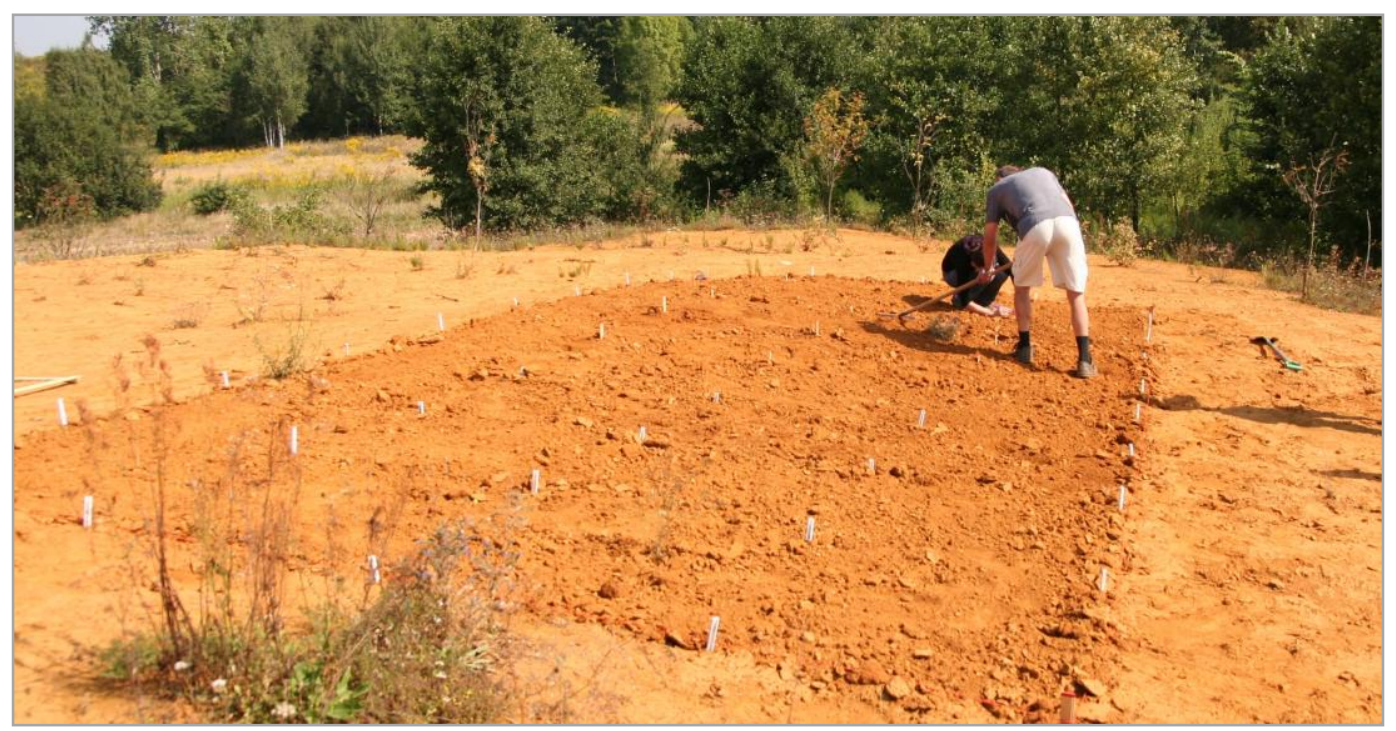

Fig. 6. View of the test plots on the "Dołki" spoil heap - ZGH Orzeł Biały in 2009 (A. Rostański)

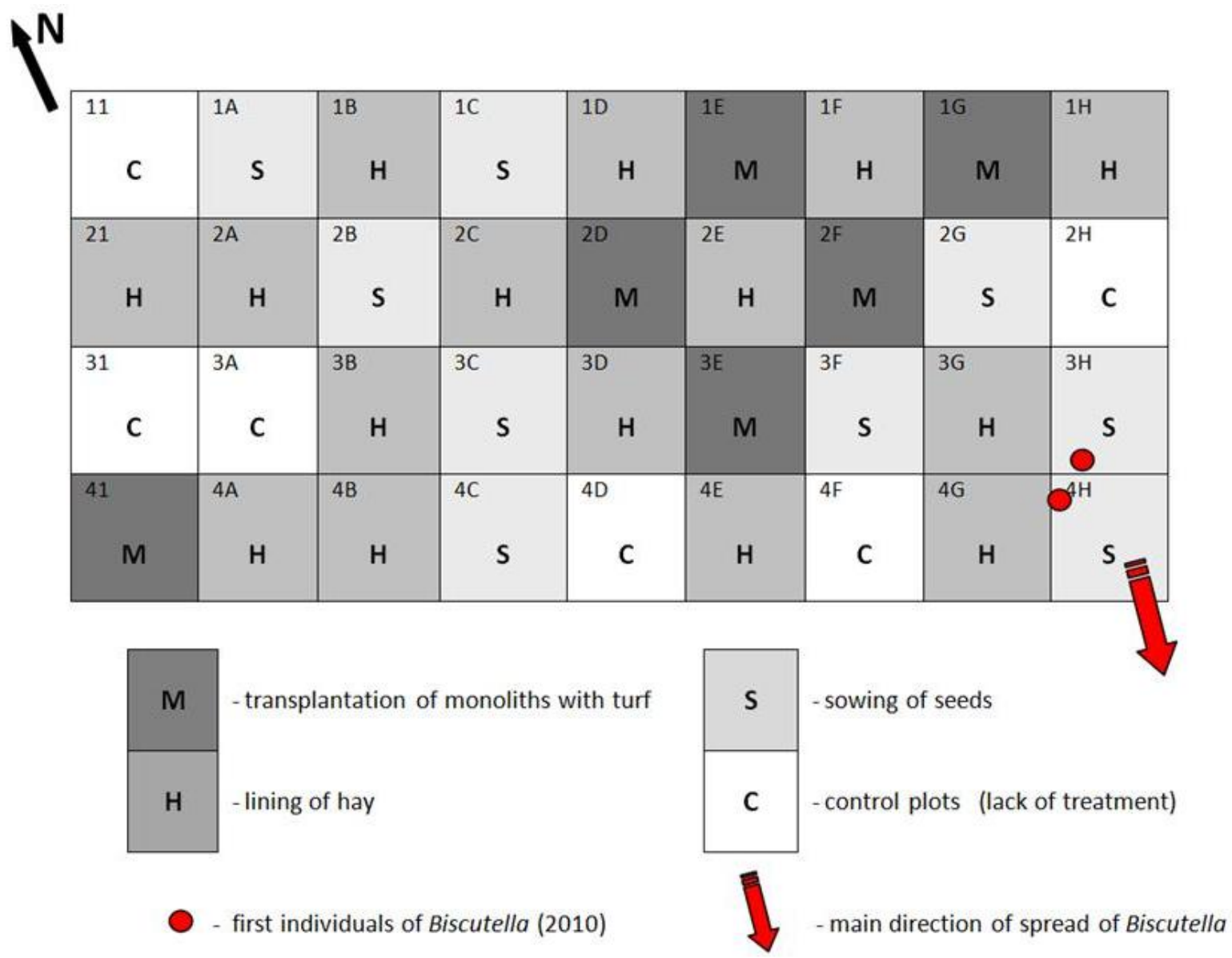

Fig. 7. The experimental layout of the plot-experiment research. The research field is divided into 36 squares (plots). Symbols inside the squares $\left(1 \times 1 \mathrm{~m}^{2}\right)$ denote the number of each plot.

\section{Results}

Observations of the three treatments made during the development of the plants in the established experimental plots, (2010-2012) were analyzed (ROSTANSKI ET AL., 2012) and revealed differences between the treatments applied.

Transplantation of fragments of turf appeared to be fully successful. Plants on all fragments of turf developed normally (Fig. 8). However, there was no plant expansion from fragments of turf to neighboring areas outside the plots.

The use of hay (mulching) - did not give the expected results. Most of the seedlings that germinated in 2010 (September) did not survive (died) until 2011(Fig. 9).

Sowing of the seeds did not bring the expected result either. Only small numbers of plant species 
germinated (Silene vulgaris, Lotus corniculatus, Daucus carota, Reseda lutea and Biscutella laevigata), forming few seedlings in the plots

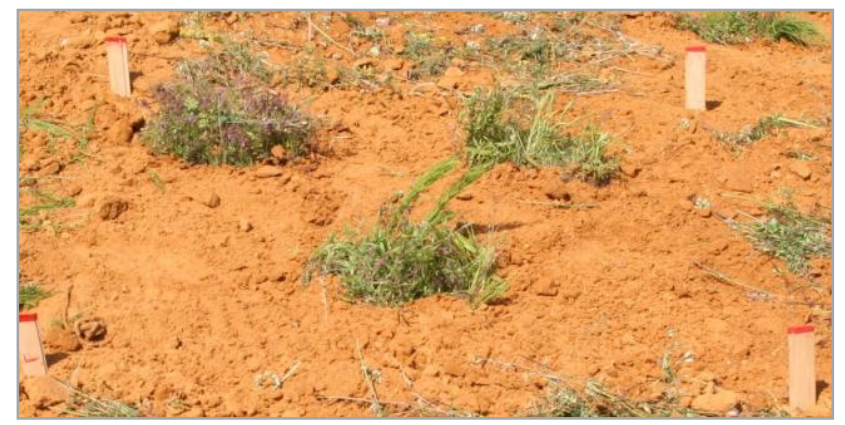

2009

Fig. 8. Comparison of turf transplanted plots in 2009 and 2013 (A. Rostański)

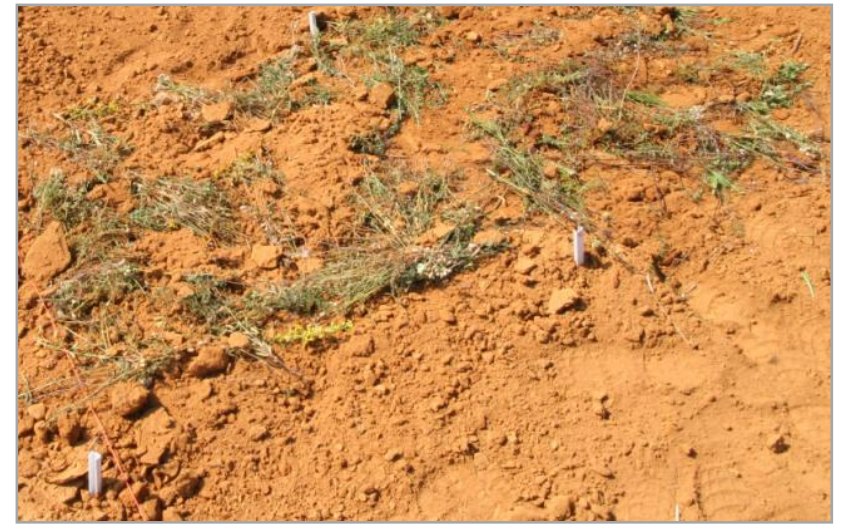

2009

Fig. 9. Comparison of hay strewn and mulched plots in 2009 and 2014 (A. Rostański)
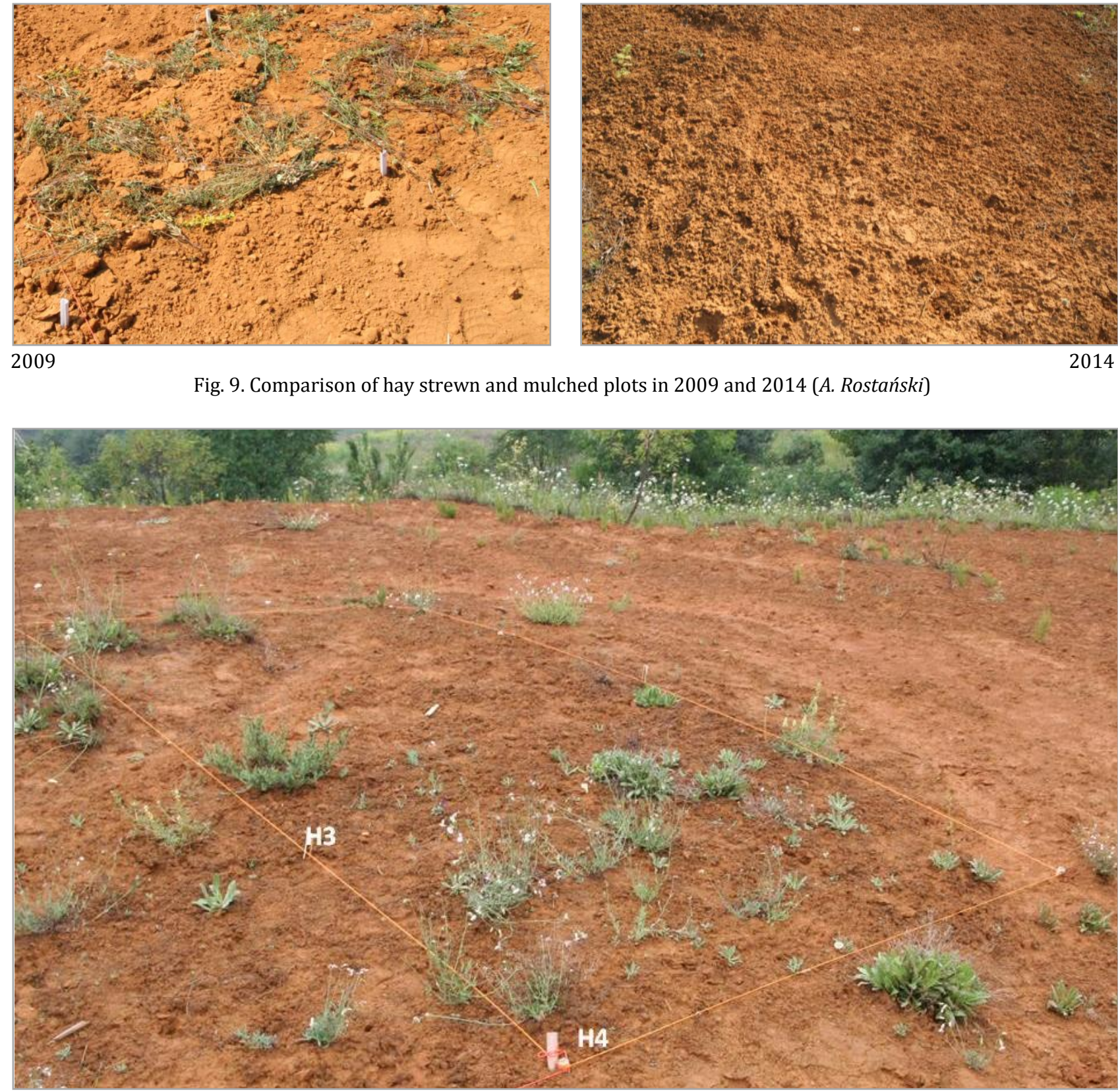

Fig. 10. Plots H3, H4 sown with seeds in 2009, in 2013 with growing Biscutella laevigata and Silene vulgaris (A. Rostański) 
On plots where no special treatments were applied (control plots) - during a 4-year observation, there was very little or no spontaneous appearance of any seedlings. In places where the seedlings were observed - in the following years degeneration and atrophy took place (RoSTAŃSKI ET AL., 2012).

The development of individuals of Biscutella laevigata revealed the most interesting results. In 2010 the seeds (originating from population in Bolesław) were sown on two plots (H3 and H4, see Fig. 6) developed initially into two seedlings. In 2011, two larger rosettes appeared and one individual started flowering. In spring 2012, the first 2 individuals came into full reproductive cycle: produced flowers and fruits. Moreover, several young seedlings and rosettes of other individuals were identified. Some young rosettes developed outside of these plots (Fig. 11). In 2013, 11 new individuals became fully developed into rosettes, bloomed and set seeds (Fig. 12). There were numerous young rosettes around the generative individuals. In 2014 on plot H3 four generative individuals grew (1 fully mature, 3 beginning flowering) and 7 seedlings in the form of differently developed rosettes. On the plot H4 - apart from the one mature individual, eight plants started flowering. In addition, the seven Biscutella laevigata seedlings were found here (Fig. 13).

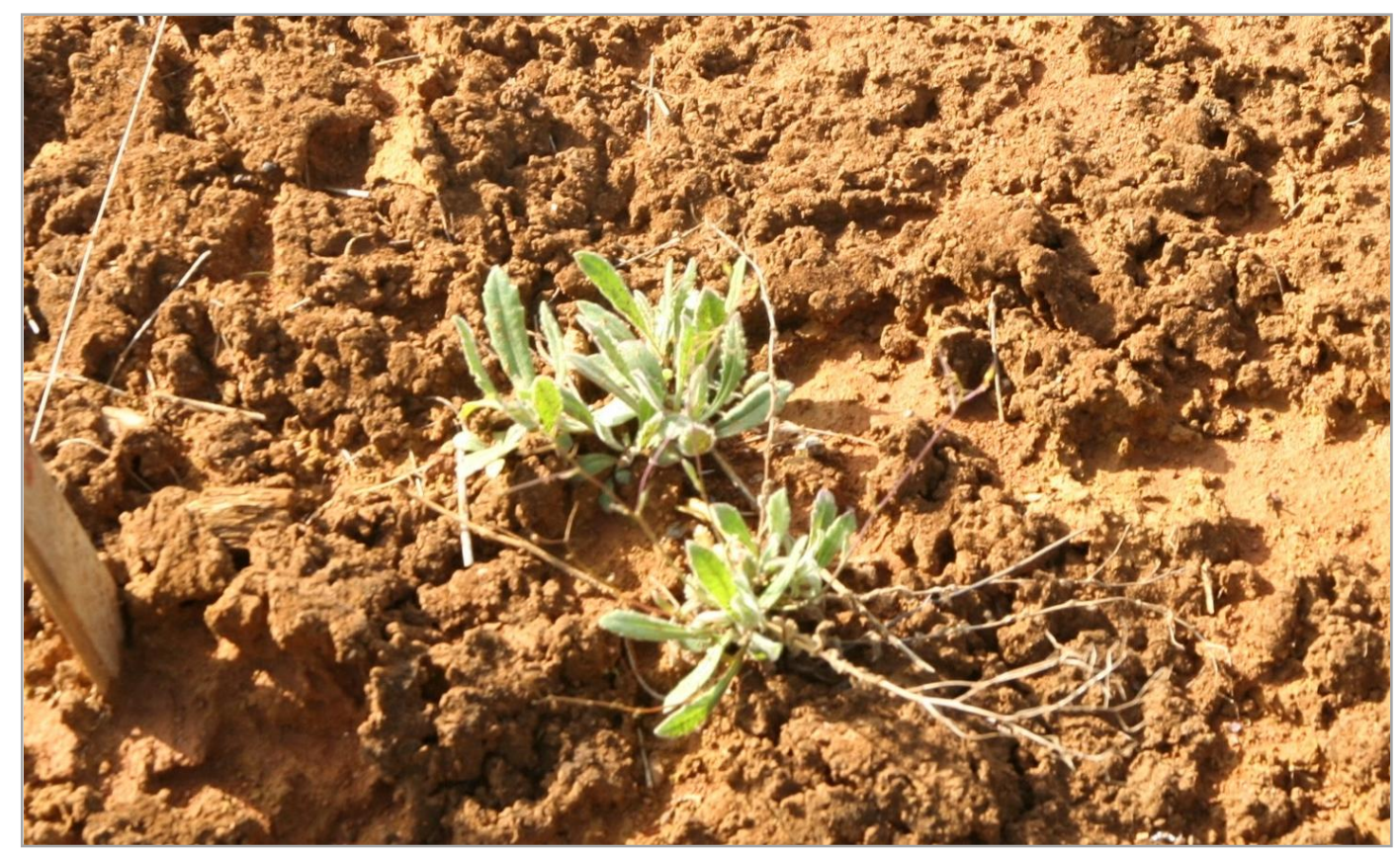

Fig. 11. Young seedlings of Biscutella laevigata in the summer of 2012 (A. Rostański)

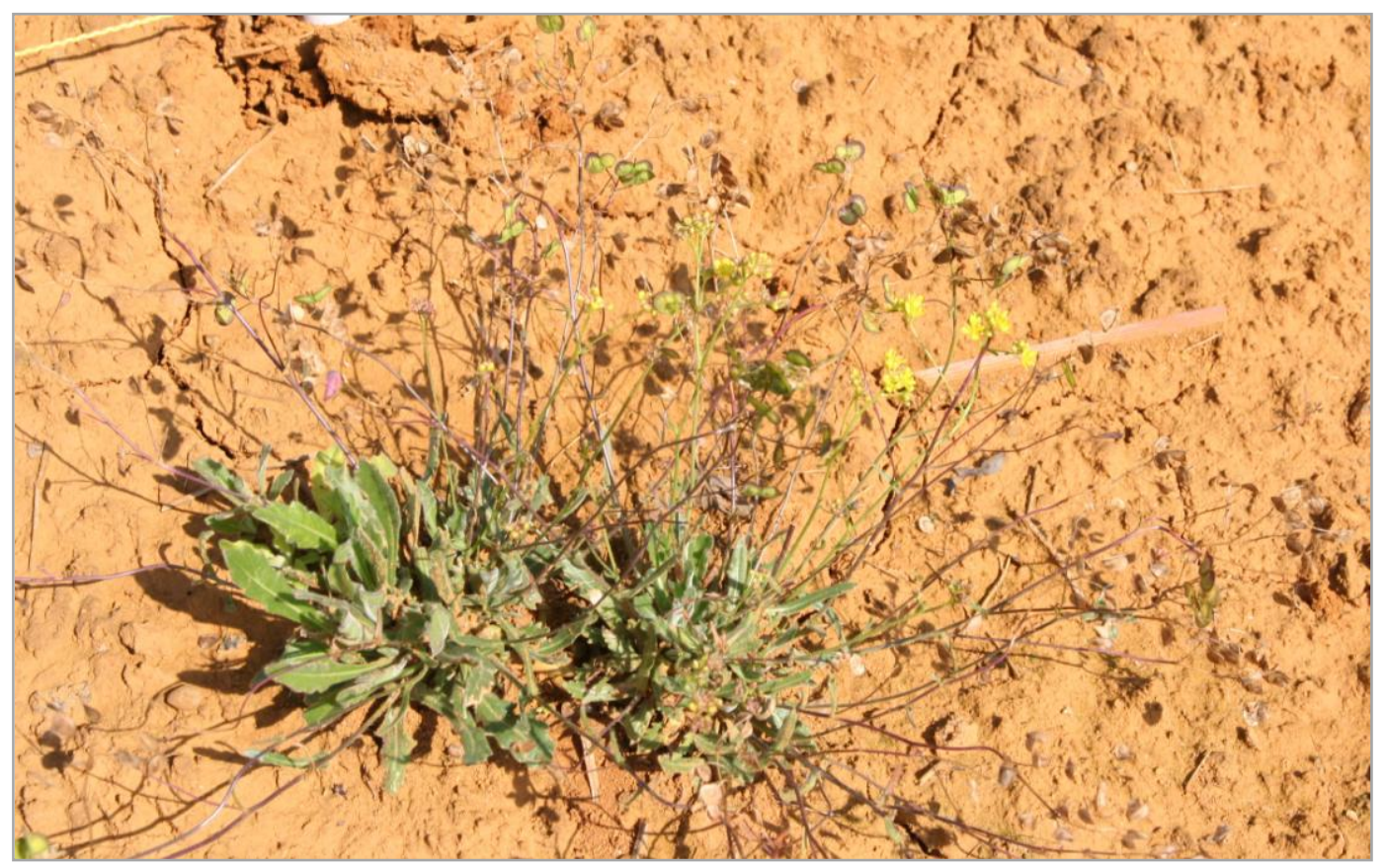

Fig. 12. Flowering plant in the summer of 2013 (A. Rostański) 
At the end of the 2014 season, all the individuals of Biscutella were counted on the "Dołki" spoil heap. In 2 plots 13 flowering plants (they had sown seeds) and 14 seedlings had been identified. Out of the plot area grew 4 specimens of flowering and 27 juveniles in the form of smaller and larger rosettes. The total number of individuals in 2014 was 58. Biscutella individuals are spreading down the slope of the heap (outside the designated test plots). The growing rosettes look healthy and are increasing in numbers every year (Figs. 6, 14). This indicates a development of the newly established population.

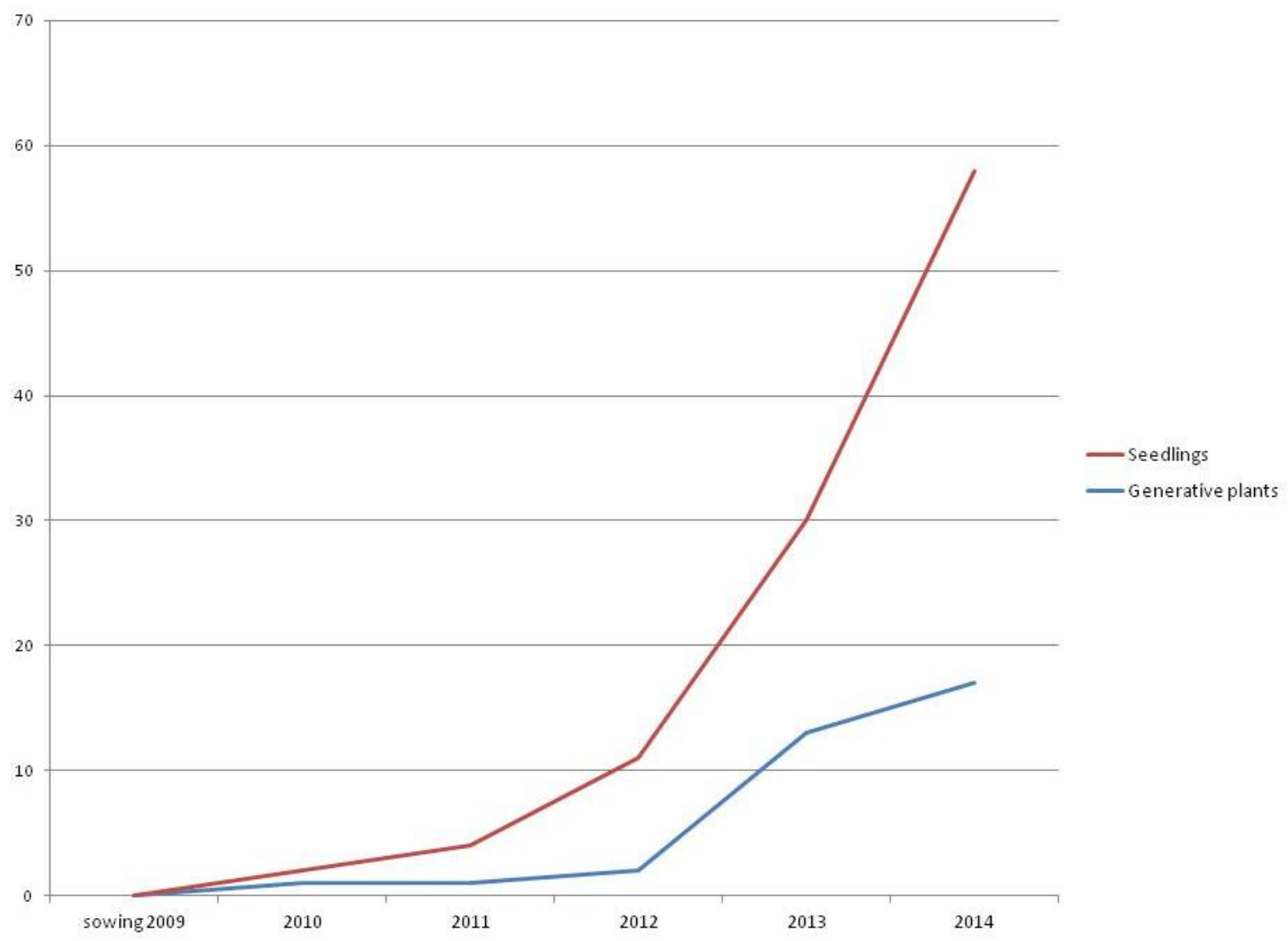

Fig. 13. Characteristics of the Biscutella population on the "Dołki"spoil heap in Piekary Śląskie: $\mathrm{A}$ - number of seedlings; $\mathrm{B}$ - number of generative plants

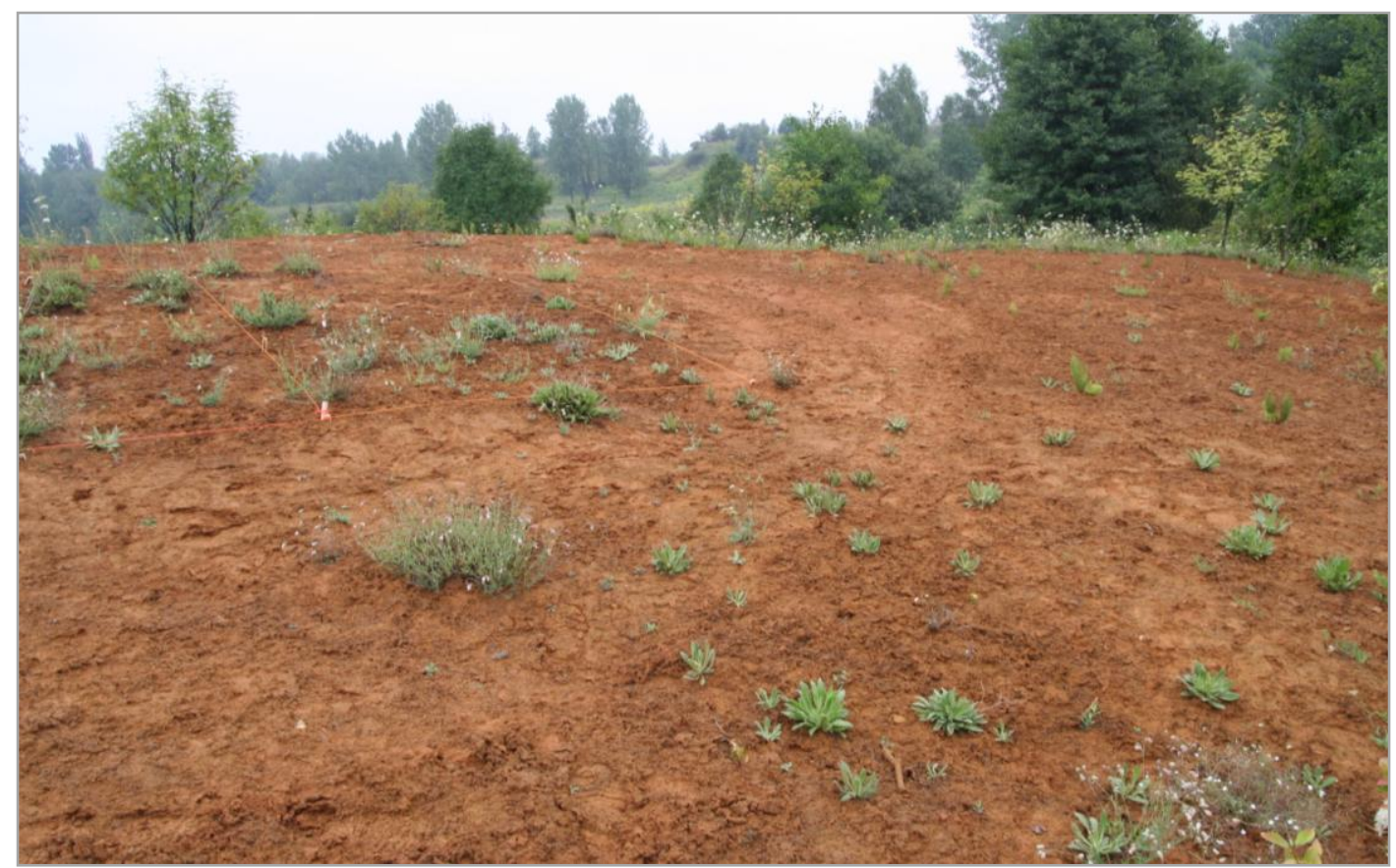

Fig. 14. Current (2014) status of the Biscutella population: seedlings of Biscutella laevigata spreading outside the experimental plots (A. Rostański) 


\section{Conclusion}

After 4 years of observations, the presence of Biscutella laevigata on the experimental plots and also outside them increased. This phenomenon can be recognized as a general trend. The studied Biscutella laevigata population is developing from year to year indicating a development of the newly established population. Recently published research (WĄSOWICZ ET AL., 2014) showing major genetic and physiological differentiation between metallicolous and non-metallicolous populations of the species in S Poland suggests, that origin of the seed material might be of major importance and that seeds from metallicolous populations may perform better when used in reclamation.

\section{References}

Babst-Kostecka A.A., Parisod C., Gode C., Vollenweider P., Pauwels M. 2014. Patterns of genetic divergence among populations of the pseudometalophyte Biscutella laevigata from southern Poland. Plant Soil, DOI 10.107/s11104014-2171-0.

Dobrzańska J. 1955. Badania florystyczno-ekologiczne nad roślinnością galmanową Bolesławia. Acta Soc. Bot. Poloniae, 24: 357-416.

Grodzińska K., Szarek-Łukaszewska G. 2009. Heavy metal vegetation in the Olkusz region (Southern Poland) preliminary study. Polish Bot. J., 54: 105-112.

Kowolik M., Szarek-Łukaszewska G., Jędrzejczyk-Korycińska M. 2010. Użytek ekologiczny „Pleszczotka Górska” w cynkowo-ołowiowym terenie pogórniczym - potrzeba aktywnej ochrony. Chrońmy Przyr. Ojczysta 66: 35-38.

Kucharski R., Rostański A., Sas-Nowosielska A., Płaza G., Gucwa-Przepióra E., Wąsowicz P. 2010. Ocena uwarunkowań ekologicznych i stanu rozwoju szaty roślinnej zwałowisk popłuczkowych „Dołki” ZGH „Orzeł Biały” w Piekarach Śląskich jako podstawa w planowaniu optymalnego sposobu rekultywacji i zagospodarowania obiektu. [in:] Skowronek J. (ed.) Innowacyjne rozwiq̨ania rewitalizacji terenów zdegradowanych. IETU-CBiDGP, Katowice - Lędziny: 64-73.

Nowak T., Kapusta P., Jędrzejczyk-Korycińska M., SzarekŁukaszewska G., Godzik B. 2011. The vascular plants of the Olkusz ore-bearing region. W. Szafer Inst. of Botany, Polish Acad. of Science, Kraków.

Pawlus M. 1985. Biscutella L., Pleszczotka. [in:] Jasiewicz A. (ed.) Flora Polski. Rośliny naczyniowe, IV. PAN, Inst. Bot., Państ. Wyd. Nauk., Warszawa - Kraków: 251-252.

Przemyski A., Piwowarczyk R. 2012. Biscutella laevigata L. in the Polish uplands - new data on its distribution from Nida Basin. Botanika - Steciana, 16: 21-29.

Rostański A., Płaza G., Sas-Nowosielska A., Gucwa-Przepióra E., Kowolik M. 2012. Określenie optymalnego sposobu rekultywacji biologicznej składowiska odpadów poflotacyjnych rud cynkowo-ołowiowych. [in:] Skowronek J. (ed.) Innowacyjne rozwiq̨zania rewitalizacji terenów zdegradowanych, IETU-CBiDGP, Katowice - Lędziny: 79-91.

Salt D. E., Blaylock M., Kumar N. P. B. A., Duschenkov V., Ensley B. D., Chet I., Raskin I. 1995. Phytoremediation: a novel strategy for the removal of toxic metal from the environment using plants. Biotechnology, 13: 468-474.

Szarek-Łukaszewska G. 2014. Rośliny hyperakumulujące metale. Kosmos, 63 (3): 443-453.

Wasowicz P., Pielichowska M., Przedpełska-Wąsowicz E. M., Bednarek P., Szarek-Łukaszewska G., Abratowska A., Wierzbicka M. 2014. Physiological and genetic differentiation between metallicolous and non-metallicolous diploid populations of alpine Biscutella laevigata (Brassicacae) in the Tatra Mountains and the northern Carpathian foreland. Ann. Bot. Fennici, 51: 227-239.

Wierzbicka M., Rostański A. 2002. Microevolutionary changes in ecotypes of calamine waste heap vegetation near Olkusz, Poland: A review. Acta Biol. Crac. Ser. Bot., 44: 7-19.

Zając A., Zając M. (eds.) 2001. Atlas rozmieszczenia roślin naczyniowych $w$ Polsce. Prac. Chorologii Komput. Inst. Bot. Uniw. Jagiellońskiego, Kraków. 